https://doi.org/10.18485/iipe_postkovid.2021.ch9

\title{
POLOŽAJ KRALJEVINE DANSKE U ODBRAMBENOJ POLITICI EVROPSKE UNIJE NAKON BREGZITA
}

\begin{abstract}
Jovanka KUVEKALOVIĆ STAMATOVIĆ ${ }^{1}$
Apstrakt: Značajan broj voljnog neučestvovanja u različitim oblastima saradnje Evropske unije, poznatijeg kao opt-out, karakterističan je za nekadašnje članstvo Ujedinjenog Kraljevstva i trenutan položaj Kraljevine Danske. Upozoravajuća nota Bregzita je tokom rasprava o poljuljanoj strateškoj perspektivi Evropske unije dosegla pitanje eventualnog istupanja drugih država članica. Na temelju diferenciranog učešća Danske u Zajedničkoj bezbednosnoj i odbrambenoj politici Evropske unije, rad analizira potencijal evropskih kormilara u preispitivanju kopenhaške politike. Inertnost Kraljevine Danske postaje naročito zabrinjavajuća tokom Bregzita, sa kojim se uporedo odvija proces rastućih evropskih odbrambenih integracija u vidu PESCO programa i Evropske inicijative za intervenciju. Oštriji stav Evropske unije prema ekskluzivitetu Danske u oblasti odbrambene politike takođe se može očekivati na osnovu produbljenih bilateralnih veza Ujedinjenog Kraljevstva sa Grenlandom. Trougao odnosa EU-Danska-Ujedinjeno Kraljevstvo počiva na strateškom interesovanju za Grenland, čime se fokus njihovih diplomatskih i odbrambenih napora izmešta sa strogo evropskog prostora na severni polarni kontinent. Cilj ovog rada je da ustanovi implikacije koje Bregzit može imati na poseban status Danske u odbrambenoj politici Evropske unije, kao jednom od novih poglavlja na putu njenog strateškog razvoja.

Ključne reči: Bregzit, Kraljevina Danska, Ujedinjeno Kraljevstvo, opt-out, Evropska unija, Zajednička bezbednosna i odbrambena politika.
\end{abstract}

\footnotetext{
${ }^{1}$ Istraživač-pripravnik u Institutu za međunarodnu politiku i privredu, Beograd. E-mail: jovankaks@diplomacy.bg.ac.rs.

Rad je nastao u okviru naučnoistraživačkog projekta „Srbija i izazovi u međunarodnim odnosima 2021. godine“, koji finansira Ministarstvo prosvete, nauke i tehnološkog razvoja Republike Srbije, a realizuje Institut za međunarodnu politiku i privredu tokom 2021. godine.
} 


\section{Uvodna razmatranja}

Na političkoj sceni Danske već decenijama unazad vodi se diskusija o tome da li evropske integracije predstavljalju izazov čvrsto utemeljenoj ideji državenacije. Dinamika ovih rasprava otvorila je prostor za nastanak dve struje mišljenja, koje polaze od zajedničkog stanovišta da Evropska unija (EU) poseduje instrumentalizovano svojstvo u privilegovanoj, ali i nametnutoj saradnji. Prvo tumačenje neguje blagonaklon stav prema EU kao jednom vidu privilegovane saradnje, dok u osnovi drugog mišljenja preovladava teza da EU ograničava spoljnu politiku Danske. ${ }^{2} \mathrm{Na}$ tragu druge perspektive, Evropska unija ne predstavlja projekat mira već naddržavnu tvorevinu koja insistira na uspostavljanju neprimerenih ograničenja državama članicama. Prateći liniju ove argumentacije može se primetiti da evroskeptičan duh Kraljevine Danske nije usamljen primer nordijskog regiona. Među njenim susedima široko je rasprostranjen konsenzus o tome da EU ne predstavlja relevantnog činioca za njihovu nacionalnu bezbednost. Politika i vrednosti EU nisu komplementarni sa očuvanjem tradicionalno nordijskog modela države blagostanja, što iziskuje drugačije oblike međuvladine saradnje. Nastojeći da održe kontinuitet istorijskog nasleđa, nordijske zemlje tragaju za multilateralnim okvirima, koji će umesto potpune integracije omogućiti visok stepen autonomije u procesu odlučivanja. ${ }^{3}$

Najveće breme nordijske izuzetnosti u Evropskoj uniji nosi Kraljevina Danska, čiji poseban status odoleva vremenu ali ne i turbulencijama koje potresaju EU poslednjih godina. $U$ plejadi dobrih ilustracija navedene tvrdnje prevagu odnosi Bregzit, imajući u vidu da predstavlja jednu od najvećih kriza novijeg datuma. U svetlu njegove političke retorike pomalja se niz pitanja, među kojima posebno izdvajamo nedoumicu o eventualnom istupanju drugih država članica. Vodeći se primerom Kraljevine Danske, cilj ovog rada je da pruži odgovor na zadatu dilemu i ustanovi implikacije koje Bregzit može imati na poseban status nordijske države. Specifične odlike njene pozicije sastoje se u kriterijumu "neposlušnosti“,

\footnotetext{
${ }^{2}$ Henrik Larsen, "Denmark and the ESDP opt-out: A new way of doing nothing?", in: Clive Archer (ed.), New Security Issues in Northern Europe: The Nordic and Baltic states and the ESDP, Routledge, London, 2008, p. 81.

${ }^{3}$ Kao jedan od primera može se navesti Kraljevina Norveška. lako nije članica Evropske unije to je ne sprečava da sa istom organizacijom razvija dobre odnose. Više o tome pogledati u sledećem članku: Nevena Stanković, „Evropsko partnerstvo sa Norveškom“, Evropsko zakonodavstvo, god. XIII, br. 51, 2015, str. 352-369.
} 
odnosno najvećem broju opt-out (voljnog neučestvovanja) u pojedinim oblastima saradnje EU. Prvi deo rada čini komparativna analiza posebnog statusa Danske i Ujedinjenog Kraljevstva u okviru EU, čime se razvija argumentacija o pravilnom odabiru konkretne studije slučaja. Uporedo sa Bregzitom odvijala se tendencija rasta evropskih odbrambenih inicijativa, zbog čega će fokus istraživanja biti usmeren ka položaju Danske u Zajedničkoj bezbednosnoj i odbrambenoj politici (ZBOP) EU, ali i Evropskoj inicijativi za intervenciju. Tom prilikom je važno osvrnuti se na bilateralan odnos Ujedinjenog Kraljevstva i Grenlanda. Proces britanskog istupanja iz evropskih integracija pratilo je produbljivanje pomenutih veza, koje se mogu negativno odraziti na teritorijalni integritet Danske, polarnu strategiju i unutrašnju koheziju EU. Polazeći od navedenih tvrdnji i reakcija evropskih zvaničnika, finalni deo rada potvrđuje hipotezu o uticaju Bregzita na ekskluzivan položaj Danske. Napuštanjem evropskih okvira, Velika Britanija je odškrinula vrata novog poglavlja u proučavanju evropskih integracija i njihove istorije. Osnovna ideja rada je da ukaže na jedan od mogućih scenarija, čije će stranice na putu do strateškog razvoja EU ispisivati politika negativne diferencijacije Kraljevine Danske.

\section{Komparativna analiza posebnog statusa Kraljevine Danske i Ujedinjenog Kraljevstva}

Danska je, zajedno sa Ujedinjenim Kraljevstvom, bila jedan od pionira koji su pregovarali o ratifikaciji Ugovora iz Mastrihta 1992. godine. Prema izveštaju Danskog instituta za međunarodne studije iz 2008. godine, inicijalni pokušaji za očuvanje autonomije u sistemu EU utrli su put britanskom modelu dezintegracije. ${ }^{4}$ Diferencijacija, ili ono što pojedini autori nazivaju „negativnim polazištem " integracije, oduvek je bila norma u različitim oblastima politike EU. ${ }^{5}$ Prema njoj se homogenost država članica oduvek smatrala nedostižnim idealom evropskih institucija. lako se isticala kao važna tema mnogih akademskih

\footnotetext{
${ }^{4}$ Benjamin Leruth, Stefan Gänzle and Jarle Trondal, "Differentiated Integration and Disintegration in the EU after Brexit: Risks versus Opportunities", Journal of Common Market Studies, Volume 57, No. 6, 2019, pp. 1385, 1388-1389, 1391-1392.

${ }^{5}$ Steven Blockmans and Dylan Macchiarini Crosson, "Differentiated integration within PESCO - clusters and convergence in EU defence", Research Report, Center for European Studies Policy, 04/2019, p. 1.
} 
rasprava, diferencirana integracija do danas ostaje na marginama političke agende EU. Britanskim povlačenjem iz evropskih okvira biva potisnuta magična formula "diferencirane unije“, dok pozitivna tumačenja danskog fenomena smenjuje izoštren akademski i diplomatski pristup. ${ }^{6}$ Položaj Kraljevine Danske u Evropskoj uniji najčešće se vezuje za veliki broj opt-out, odnosno voljnog neučestvovanja u pojedinim oblastima evropske saradnje. Njena titula prve nordijske države koja se pridružila evropskoj kolevci 1973. godine, ostaje u senci ambivalentnog stava prema pitanjima koja se tiču državnog identiteta. Prema danskom ustavu (član 20), ugovor o delegiranju suvereniteta međunarodnim telima može se ratifikovati na osnovu većine od pet šestina članova parlamenta ili prostom većinom i referendumom. ${ }^{7}$ Visoki zahtev za ratifikacijom i drugi institucionalni postupci čine konsenzualnu političku kulturu Danske, koja povodom određenih oblasti evropske saradnje ispoljava duboku polarizaciju mišljenja. Većina poslanika u danskom parlamentu glasala je za ratifikaciju Ugovora iz Mastrihta. ${ }^{8}$ Međutim, uprkos jasnom signalu najvišeg zakonodavnog tela, 50,7\% građana Danske je na referendumu iz 1992. godine glasalo protiv Ugovora o Evropskoj uniji. Rezultat je iznenadio politički establišment, zbog čega su vodeći političari ishod referenduma opisali kao „najveću krizu danske politike od Drugog svetskog rata". ${ }^{9}$ Narodno odbijanje Ugovora u junu 1992. godine dovelo je do stopiranja važnih delova integracionih procesa, uključujući bezbednosnu i odbrambenu dimenziju. Pre nego što joj se posvetimo u narednim redovima, treba pomenuti da su Danskoj odobrena izuzeća u četiri oblasti evropske politike: 1) Državljanstvo EU; 2) Ekonomska i monetarna unija; 3) Zajednička bezbednosna i odbrambena politika, i 4) Sloboda, bezbednost i pravda. Zajedničku bezbednosnu i odbrambenu politiku karakteriše vrlo skromna

\footnotetext{
${ }^{6}$ Više o diferenciranoj Evropskoj uniji pogledati: Maja Kovačević, Evropska diferencirana unija, Fakultet političkih nauka, Univerzitet u Beogradu, 2020.

${ }^{7}$ Denmak's Constitution of 1953, p. 5, Internet: https://www.constituteproject.org/ constitution/Denmark_1953.pdf?lang=en, 10/08/2021.

${ }^{8}$ Maya Sion, "The Politics of Opt-out in the European Union: Voluntary or Involuntary Defection?", Proceedings of the IWM Junior Fellows' Conference, Winter 2003, p. 9.

${ }^{9}$ Lee Miles, "Domestic influences on Nordic security and defence policy: from the perspective of fusion", in: Alyson J. K. Bailes, Gunilla Herolf and Bengt Sundelius (eds), Institutional and national politics, The Nordic Countries and the European Security and Defence Policy, International Peace Research Institute/Oxford University Press, Stockholm, 2006, pp. 83-84.
} 
unutrašnja diferencijacija. Danska predstavlja jedinu državu članicu koja je tražila i dobila saglasnost za neučestvovanje u oblasti bezbednosne i odbrambene politike. U skladu s tim, ona ne učestvuje u odbrambenim aktivnostima EU i nije član njenih odbrambenih inicijativa, poput Evropske odbrambene agencije. Od stupanja na snagu Ugovora iz Mastrihta (1. novembra 1993. godine) do 1. januara 2003. godine, Danska je devet puta aktivirala odbijanje u saradnji sa odbranom. Izuzeća su primenjena u vezi sa evakuacijom civila EU iz zona sukoba, kao i pružanjem pomoći u otklanjaju mina na prostoru bivše Jugoslavije. Takođe ne učestvuje u obezbeđivanju trupa ili zaliha vojnim operacijama koje se odvijaju pod okriljem Zajedničke bezbednosne i odbrambene politike EU. ${ }^{10}$ Do danas, Kopenhagen ne doprinosi nijednom obliku vojne saradnje koja ima za cilj unapređivanje evropske odbrambene politike. ${ }^{11}$

Tragajući za motivima evroskeptičnog raspoloženja nordijskih zemalja, pojedini autori navode da EU predstavlja jedini multilateralni okvir bez nasleđa bezbednosne politike iz perioda Hladnog rata. Imajući u vidu činjenicu da je Danska članica NATO saveza, uzdržanost u odbrambenoj politici EU mahom je shvaćena kao odraz njenog oklevanja da se odrekne nacionalnog suvereniteta u tradicionalnom bezbednosnom području. ${ }^{12}$ Prema tome, slabo interesovanje za integrisani pristup evropskoj bezbednosti pripisuje se dominantno atlantističkoj orijentaciji, koja iziskuje visoku posvećenost članstvu u Severnoatlantskoj zajednici. ${ }^{13}$ Posebno važna činjenica za Kraljevinu Dansku je da bezbednosni identitet malih država članica NATO saveza može biti osporen, ako se na vojnu moć EU gleda kao na pretnju koja izaziva transatlantske odnose. ${ }^{14}$

${ }^{10}$ Frank Schimmelfennig, Dirk Leuffen and Berthold Rittberger, "The European Union as a system of differentiated integration: interdependence, politicization and differentiation", Journal of European Public Policy, Vol. 22, No. 6, 2015, pp. 777-778.

${ }^{11}$ Bernard Stahl, Henning Boekle, Jorg Nadoll and Anna Johannesdottir, "Understanding the Atlanticist-Europeanist Divide in the CFSP: Comparing Denmark, France, Germany and the Netherlands", European Foreign Affairs Review, Volume 9, Issue 3, 2004, pp. 420-421.

12 Pernille Rieker, "The Nordic countries and EU security policy: convergent or divergent agendas?", in: Alyson J. K. Bailes, Gunilla Herolf and Bengt Sundelius (eds), Institutional and national politics, The Nordic Countries and the European Security and Defence Policy, International Peace Research Institute/Oxford University Press, Stockholm, 2006, p. 303.

${ }^{13}$ Ibid., pp. 306-307.

${ }^{14}$ Sredinom devedesetih godina XX veka pripadnici danskih oružanih snaga su pod okriljem NATO i UN kontigenata aktivno učestvovali u ratnim sukobima na Kosovu, Iraku i 
Ujedinjeno Kraljevstvo je takođe oklevalo da u potpunosti integriše mnoge aspekte pravne tekovine EU, uglavnom zahvaljujući strahu Britanaca da će biti podređeni „Evropi“ i da će izgubiti vitalne aspekte identiteta, kulture i prava. Saglasno tome, Britanija je odlučila da pribegne opting-out sistemu u sledećim oblastima evropske politike: 1) ekonomske i monetarne unije; 2) Šengenskog područja; 3) područje Sloboda, bezbednost i pravda, i 4) Povelja o osnovnim ljudskim pravima. Prema rečima nekadašnjeg britanskog premijera Džona Mejdžora (John Major), put diferencirane integracije bio je najbolji mogući odgovor na dilemu sa kojom se ova ostrvska zemlja suočila. Drugačiji pristup integracijama predstavljao je britansku želju da zadrži nacionalni suverenitet, uz istovremeno učešće u ključnim aspektima politike EU. Transatlantski odnosi su oduvek bili važan stub bezbednosne politike zemlje i Ujedinjeno Kraljevstvo je ostvarilo značajne koristi kao evropska zemlja koja je među vodećim članicama NATO. Britanska spoljna politika po uzoru na Dansku naginje ka atlantističkoj orijentaciji, zbog čega se može očekivati da će nakon Bregzita nastojati da evropsku dimenziju sve više zameni evroatlantskom komponentom. ${ }^{15}$

Na polju bezbednosne politike, EU se često opisuje kao gotovo idealna organizacija za male države članice. ${ }^{16}$ Ipak, Danska je izabrala da ostane van domašaja evropske odbrambene politike. Njen položaj se može uporediti sa „integracionom dilemom", odnosno situacijom u kojoj država mora da odluči da li će se odreći značajnog dela svog suvereniteta ili želi insistirati „na svojoj nezavisnosti uz opasnost da bude napuštena“ “. ${ }^{17}$ Tumačenje opt-out se najčešće izvodi iz koncepta integracione dileme, koji pretpostavlja da se sve države suočavaju sa teškom situacijom izbora kada dođu do određene faze u procesu nadnacionalne, političke integracije. Nadovezujući se na geopolitičko razumevanje evropskih integracija, neoklasični realisti su razvili hipoteze o

Avganistanu. Anders Wivel, "The Security Challenge of Small EU Member States: Interests, Identity and the Development of the EU as a Security Actor", Journal of Common Market Studies, Volume 43, No. 2, 2005, p. 406.

${ }^{15}$ Miloš Petrović, „Brexit kao ishod ambivalentne britanske politike prema evropskoj integraciji“, Međunarodni problemi, Vol. LXXII, br. 3, 2020, str. 534, 559.

${ }^{16}$ Anders Wivel, "The Security Challenge of Small EU Member States: Interests, Identity and the Development of the EU as a Security Actor", op. cit., pp. 393-412.

${ }^{17}$ Gorm Rye Olsen and Jess Pilegaard, "The Costs of Non-Europe? Denmark and the Common Security and Defence Policy", European Security, Volume 14, Issue 3, 2005, pp. 339-360. 
integracionoj dilemi, prema kojima države članice sa izuzećima biraju manju sposobnost uticaja, kako bi ostvarile veću autonomiju u poređenju sa državama članicama bez izuzeća. ${ }^{18}$ Drugim rečima, opting-out sistem predstavlja dobrovoljnu izolaciju koja doprinosi većoj autonomiji država članica, ali i gubitku uticaja prilikom donošenja odluka. Odbijanje saradnje u pojedinim oblastima evropske politike pruža veću slobodu državama članicama, ali i prilika da zaobiđu proces evropeizacije. Premda je iz perspektive realističke tradicije međunarodnih odnosa reč o izrazito negativnom fenomenu, diplomatska praksa je pokazala da odbijanje saradnje u pojedinim oblastima politike EU može biti pragmatično rešenje za različite interese država članica.

Za male države (poput Danske) integraciona dilema je veća nego za veće države (poput Ujedinjenog Kraljevstva). Druga kategorija zemalja ima privilegiju da uspešno zaustavi ili čak ugrozi proces integracija, ako uoči nove političke inicijative koje su u suprotnosti sa njihovim nacionalnim interesima. ${ }^{19}$ Izuzeće u oblasti odbrambene politike može biti tumačena dvojako: kao ograničeni doprinos odrambenoj politici EU, ali i način putem kojeg Danska uspostavlja jasne granice do kojih ova organizacija može uticati na pitanja od nacionalnog interesa. ${ }^{20}$ Do sličnog zaključka dolaze i druge politikološke studije, koje se uporednom analizom dveju kraljevina bave iz perspektive diferenciranih integracija. Sa njihovog stanovišta, diferencirana integracija povećava kapacitete za rešavanje problema, efikasnost odlučivanja EU i legitimitet kao dobrovoljni konsenzus država i naroda. Zajedno sa Velikom Britanijom, Danska je evropski šampion diferencirane integracije. Kada je reč o Velikoj Britaniji, evroskeptične vlade su rutinski obezbeđivale izuzetke u međuvladinim pregovorima o reviziji Ugovora o Mastrihtu. Za razliku od njih, danske vlade su obično podržavale produbljivanje integracije, ali uz velika ograničenja naknadnih referenduma. Dansko biračko telo je tokom 2000. i 2015. godine imalo priliku da potvrdi ili opovrgne rezultate prethodno izglasanih odluka u vezi sa monetarnom unijom

\footnotetext{
${ }^{18}$ Hans Mouritzen and Anders Wivel, The Geopolitics of Euro-Atlantic Integration, Routledge, London, 2004, p. 27.

${ }^{19}$ Rebecca Adler-Nissen, "The Diplomacy of Opting-out: A Bourdieudian Approach to National Integration Strategies", Journal of Common Market Studies, Volume 46, No. 3, 2008, p. 667.

${ }^{20}$ Henrik Larsen, "Denmark and the ESDP opt-out: A new way of doing nothing?", op. cit., pp. 81-82.
} 
i pravosuđem. S druge strane, ZBOP sadrži drugačiju političku dimenziju, koja posle negativne ratifikacija iz 1992. godine više nije dovođena u pitanje. ${ }^{21}$ Oslanjajući se na uvide prethodnih analiza, možemo izvesti konstataciju da položaj Danske u odbrambenoj politici EU predstavlja jednu od glavnih odlika njene negativne diferencirane integracije. Zaštita nacionalnih interesa iziskuje drugačije političke aranžmane, koji odražavaju minimalistički pristup evropskim integracijama. ${ }^{22}$ Sledeći njegovu metodologiju odlučivanja, principijelnost britanskih i danskih izuzetaka užurbano menja političku agendu evropeizovanih diplomata. ${ }^{23}$

\section{Grenland kao novo mesto pomirenja Danske i Evropske unije u Zajedničkoj bezbednosnoj i odbrambenoj politici}

Treće, i ujedno centralno, poglavlje rada sagledava položaj Kraljevine Danske u kontekstu rastućih evropskih integracija i Bregzita. Prvi deo predstavlja kratak pregled opštih karakteristika Stalne strukturirane saradnje (Permanent Structured Cooperation - PESCO) i Evropske inicijative za intervenciju (European Intervention Initiative - EI2), sa posebnim osvrtom na ulogu danskog opt-out u odbrambenoj politici EU. Stalna strukturirana saradnja predstavlja deo ZBOP, koji je osmišljen da produbi evropske integracije i razvije koncept evropskog suvereniteta. Na prvi pogled može izgledati da je stvaranjem PESCO inicijative načinjen prvi korak ka stvaranju evropske vojske, koju je predsednik Evropske komisije, Žan Klod Junker (Jean-Claude Juncker) predlagao u martu 2015. godine. Bez daljeg upliva u velike ambicije ovog evropskog projekta, PESCO treba sa ove distance posmatrati kao rezultat potrebe za novim pristupom koji će održati Veliku Britaniju angažovanom u evropskoj odbrani i nakon Bregzita. ${ }^{24}$ Prvi inicijali

${ }^{21}$ Dominik Schraff and Frank Schimmelfennig, "Does differentiated integration strengthen the democratic legitimacy of the EU? Evidence from 2015 Danish opt-out referendum", European Union Politics, Vol. 21, No. 4, 2020, pp. 594, 597, 608.

${ }^{22}$ Vlastimil Fiala, "Decisions Concerning the 'Opt-Out' as an Instrument for Protecting National Interests", Contemporary European Studies, No. 1, 2006, p. 64.

${ }^{23}$ Rebecca Adler-Nissen, "The Diplomacy of Opting-out: A Bourdieudian Approach to National Integration Strategies", op. cit., p. 681.

${ }^{24}$ Neno Hristov, "European Intervention Initiative vs Common European Army", International E-Journal of Advances in Social Sciences, Vol. IV, Issue 12, December 2018, p. 692. 
Stalne strukturirane saradnje EU naziru se u tekstu Ugovora iz Lisabona, koji je ratifikovan 2009. godine. Međutim, put do formalnog pokretanja PESCO programa iz 2017. godine bio je dug. Sa formiranjem nove odbrambene platforme istovremeno se predlaže osnivanje Evropskog fonda za odbranu (European Defence Fund - EDF) u iznosu od 13 milijardi evra za podsticanje razvoja vojnih sposobnosti. ${ }^{25}$ PESCO program, ili kako ga pojedini autori nazivaju „,šengen odbrane“26, obuhvata saradnju između 25 zemalja. Od prethodnih inicijativa razlikuje se po tome što su odluke njegovog Saveta pravno obavezujuće. Dosadašnji oblici saradnje u oblasti odbrambene politike nizali su neuspehe usled nepomirljivih težnji država članica. Nasuprot tome, PESCO je institucionalno sofisticiran aranžman koji kombinuje odbrambene aspekte državnog suvereniteta u međuvladinom procesu. ${ }^{27}$ Pod okriljem njegovog programa, države članice izrađuju godišnji nacionalni plan implementacije, koji potom zahteva procenu Visokog predstavnika. Postupanje država članica slično je kao u NATO procesu odbrambenog planiranja, gde se države članice obavezuju na davanje detaljnog obrazloženja, ukoliko ne ispune zadate ciljeve. PESCO program predstavlja odbrambeni mikrokosmos, koji za razliku od pređašnjih kolektivnih aranžmana obezbeđuje veću posvećenost država članica. Značajnu podršku ostvarivanju ovog multinacionalnog projekta pruža Evropska komisija putem Evropskog odbrambenog fonda, koji za PESCO projekte predviđa dodatni bonus od $10 \%$. Važan pomak je načinjen time što inicijativa za pokretanje Stalne strukturirane saradnje nije potekla iz Brisela, već od država članica koje su na sebe preuzele ulogu obnavljanja odbrambenih napora. ${ }^{28}$ Imajući u vidu da podsticaji za njegov multinacionalni projekat ne dopiru od SAD ili NATO saveza, PESCO program je važan aspekt unutrašnje kohezije i strateške autonomije EU. Izuzeće u oblasti ZBOP sprečava Dansku da učestvuje u realizaciji PESCO

${ }^{25}$ Steven Blockmans and Dylan Macchiarini Crosson, "Differentiated integration within PESCO - clusters and convergence in EU defence", op. cit., p. 2.

${ }^{26}$ Andrew Retmman, "France and Germany propose EU 'defence union'”, EU Observer, 12 September 2016, Internet: https://euobserver.com/foreign/135022, 10/07/2021.

27 Simon Sweeney and Neil Winn, "EU security and defence cooperation in times of dissent: analysing PESCO, the European Defence Fund and the European Intervention Initiative (EI2) in the shadow of Brexit", Defence Studies, Volume 20, Issue 3, 2020, pp. 233-234.

${ }^{28}$ Francuska i Nemačka su uzele inicijativu na bilateralnom samitu 13. jula 2017. godine, podnošenjem detaljnog predloga. Sven Biscop, "European Defence: Give PESCO a chance", Survival, Vol. 60, No. 3, 2018, pp. 162-163. 
programa, iako je on od suštinskog značaja za stvaranje „odbrambene unije“. ${ }^{29}$ Zbog velikih ulaganja u transatlantske odnose, nema naznaka da će danska vlada početi da podržava ideju evropske vojske ili strateške autonomije EU. Danska teritorijalna odbrana, koja počinje duž baltičke granice NATO saveza prema Rusiji, nema dostojnu alternatvu kolektivne odbrane izuzev Alijanse. Poslednjih godina naročito u svetlu političke kritike Trampove (Donald Trump) administracije i rasprave o "moždanoj smrti NATO“. Primera radi, glavna tema na jednom od sastanaka francuskog predsednika Makrona i danskog premijera Rasmusena (Lars Løkke Rasmussen) tokom 2018. godine, bilo je preispitivanje opt-out u oblasti evropske odbrambene politike. Tokom ovog samita, predstavnici dveju zemalja su izneli konstataciju o promeni transatlantskih odnosa, aludirajući na nepredvidivo ponašanje Donalda Trampa prema svojim saveznicima. Izmenjeni bezbednosni kontekst naveo je dansko političko rukovodstvo na razmatranje opcije o povlačenju izuzeća iz evropske odbrambene saradnje. ${ }^{30}$ Pokušaje desničarske vlade u poništavanju danskog opt-out sprečio je dolazak socijaldemokrata na vlast 2019. godine. Njihov politički program obesmislio je svaku raspravu o evropskoj odbrani, kako ne bi uticala na zanemarivanje privilegovanih transatlantskih partnera-SAD, Kanade i Ujedinjenog Kraljevstva. ${ }^{31}$ Pomenuti samit je važno posmatrati iz ugla danskih spoljnopolitičkih prioriteta, ali i perspektive Makronovih diplomatskih napora da se u svetlu najnovijih dešavanja, obnovi vizija o stvaranju evropske odbrambene unije. Procene izveštaja Danskog instituta za međunarodne studije pokazuju da su implikacije danskog opt-out u odbrambenoj politici EU značajno porasle tokom poslednjih deset godina. Autori ove analize smatraju da je moguće predvideti zaštitu danskih odbrambenih interesa, u zavisnosti od toga kako će se dinamika saradnje u ovoj oblasti evropske politike odražavati na njen status izuzeća. Prema njihovoj logici razmišljanja, za ostvarivanje evropske strateške autonomije proces rastućih odbrambenih inicijativa doprinosi većem ostvarivanju danskih nacionalnih interesa, koji tim putem ostaju zaštićeni. Suprotno tome, ukoliko odbrambena

\footnotetext{
${ }^{29}$ Sten Rynning, National Expectations regarding the European Defence Fund: The Danish Perspective, Armament Industry European Research Group, France, April 2020, pp. 3-4.

30 "Denmark reconsidering EU defense opt-out after meeting with Macron", Deutsche Welle, 28.08.2018, Internet: https://www.dw.com/en/denmark-reconsidering-eu-defense-optout-after-meeting-with-macron/a-45262172, 11/07/2021.

${ }^{31}$ Sten Rynning, "National Expectations regarding the European Defence Fund: The Danish Perspective", op. cit., p. 4.
} 
saradnja EU bude stagnirala, može doći do unutrašnjeg neslaganja među državama članicama..$^{32} \mathrm{U}$ radu zastupamo drugačije stanovište, prema kojem će usled produbljivanja evropskih odbrambenih integracija dolaziti do sve većeg pritiska evropskih državnika na povlačenje danskog opt-out.

Drugi deo poglavlja posvećen je Evropskoj inicijativi za intervenciju, koja je pokrenuta od strane francuskog predsednika Makrona (Emmanuel Jean-Michel Frédéric Macron) u junu 2018. godine. Za razliku od PESCO programa, Evropska inicijativa za intervenciju ne predstavlja deo ZBOP. EI2 nastoji da evropsku vojnu saradnju uzdigne na političko-strateški nivo razmišljanja, uspostavljanjem zajedničke strateške kulture između država učesnica. Danska je kao država osnivač preuzela vođstvo u pozivanju nordijskih suseda na pridruživanje inicijativi, počevši od Finske koja je postala učesnik 2018. godine, do Švedske i Norveške 2019. godine. lako je još uvek neizvestan pravac u kojem će se dalje odvijati El2, za sada je očekivan fokus na region Sahela, pre svega Mali. ${ }^{33} \mathrm{U}$ pogledu strateškog sadržaja, El2 naglašava izazove sa kojima se suočava Evropa zbog kontinualnih ranjivosti u južnom susedstvu, uglavnom Mediteranu, regiji Sahela i Bliskog istoka. Neobavezujuća priroda El2 ga jasno određuje kao pogodniju alternativu PESCO programa, kada se radi o učešću u vojnim operacijama. PESCO održava fokus projekata na neborbenim područjima obuke i podrške (logistike) dok, s druge strane, El2 predstavlja odbrambenu platformu koja podržava zapadno orijentisani blok i njegovu hegemoniju u međunarodnom sistemu. Uz proklamovanu nameru za izgradnjom strateške autonomije EU, Makron istovremeno ispoljava spremnost da pokretanjem El2 dobije širu podršku evropskih partnera za tradicionalno važnu ulogu u južnom susedstvu. Prednost njihove saradnje je što u odnosu na PESCO inicijativu mogu okupljati države koje nisu deo EU (Velika Britanija) ili sprovode opt-out u oblasti njene odbrambene politike (Kraljevina Danska). ${ }^{34}$ Neobična vizija evropske bezbednosti

32 "European defence cooperation and Denmark. The Danish opt-out in defence", Danish Institute for International Studies, 23 April 2020, Internet: https://www.diis.dk/en/ research/european-defence-cooperation-and-denmark-the-danish-opt-out-on-defence, 5/07/2021.

${ }^{33}$ Maren Garberg Bredesen, "The Shifting Boundaries of Nordic Defence Cooperation", Research paper, Norwegian Institute of International Affairs, 2020, p. 5.

${ }^{34}$ Matthew David Huntley, "European defence policy at a crossroads - Germany preserving the status quo and France seeking change?", European Politics and Society, 2020, pp. 7-9. 
obavezuje Dansku na kulturu vojnog aktivizma, pod kojom se podrazumeva da trupe njenih oružanih snaga doprinose borbenim aktivnostima na otvorenim frontovima i jačanju bilateralnih partnerstava sa Ujedinjenim Kraljevstvom i Francuskom. Sastavni deo njenog pristupa čini učešće u El2, kao i angažovanje danskih trupa u vojnoj operaciji Barkhan (Barkhane), koja se od 2014. godine pod rukovodstvom Francuske odvija u regionu Sahela. ${ }^{35}$ Stremeći jednom obliku vojnog avanturizma, Danska pravi galističke rezerve koje joj pomažu da se ogradi od političke vizije strateške autonomije EU. Na tom putu, ona projektuje svoju koncepciju evropske bezbednosti, koja bi trebalo da počiva na promociji koordinisanog aktivizma evropskih nacija u skladu sa kontekstom transatlantskog partnerstva. Suočena sa evroskeptičnim raspoloženjem biračkog tela i marginalizacijom u strateškoj perspektivi EU, danska vlada odlučno nastoji da neguje bilateralne odnose sa evropskim državama, ali i SAD. ${ }^{36}$

Britansko povlačenje iz EU i proaktivna evropska politika predsednika Makrona bitno menjaju dinamiku odnosa u okviru EU. ${ }^{37}$ Nordijske države članice gledaju na preporod francusko-nemačkog tandema sa pomešanim osećanjima: s jedne strane, imaju snažan interes za dobro funkcionisanje Unije, koja je sposobna da se reformiše; dok, s druge strane, izražavaju zabrinutost povodom uticaja francusko-nemačke osovine na jedinstvo EU. Kako bi nadoknadile gubitak važnog ekonomskog partnera, nordijske države na posledice Bregzita reaguju unapređivanjem saradnje sa Velikom Britanijom, u oblasti liberalnih ekonomskih politika. ${ }^{38}$ Polazeći od navedene konstatacije, u nastavku poglavlja pokušavamo da utvrdimo kako se povećano interesovanje Velike Britanije za Grenland može negativno odraziti na polarnu strategiju EU. Potpisivanjem Memoranduma o razumevanju i jačanju saradnje u ribarstvu između Grenlanda i Ujedinjenog Kraljevstva, u novembru 2020. godine, bio je znak da se nekadašnja država

${ }^{35}$ Sten Rynning, "National Expectations Regarding The European Defence Fund: The Danish Perspective", op. cit., pp. 6-7.

${ }^{36}$ Anders Wivel, "Between Paradise and Power: Denmarks Transatlantic Dillemma", Security Dialogue, Vol. 36, No. 3, September 2005, pp. 418-419.

${ }^{37}$ Više o spoljnoj politici francuskog predsednika Makrona pogledati u tekstu: Nevena Stanković, „Glavne odrednice spoljne politike Emanuela Makrona“, Međunarodna politika, God. LXXI, br. 1179-80, 2020, str. 65-94.

38 Piret Kuusik and Kristi Raik, "The Nordic-Baltic Region in the EU: A Loose Club of Friends", European Policy Analysis, Swedish Institute for European Policy Studies, Issue 2018, p. 9. 
članica priprema za napuštanje zajedničke ribarske politike EU krajem decembra. Sporazum bi trebalo da omogući bolju saradnju zemalja po nizu pitanja, kao što su upravljanje ribarstvom, prerada, istraživanje, marketing i distribucija. ${ }^{39}$ lako predstavlja samoupravnu autonomnu teritoriju pod suverenitetom Danskog kraljevstva, Grenland ima pravo da samostalno zaključuje ugovore sa drugim državama, kao subjekat međunarodnog prava. Nakon Bregzita može se očekivati da će Grenland, u znatno većoj meri, koristiti pravne olakšice kako bi uredio svoje akvatorijalno prostranstvo i rešio problem teritorijalne demarkacije. Prvi korak ka tome načinjen je donošenjem akta o samoproglašenoj nezavisnosti Grenlanda 2009. godine. Ujedinjeno Kraljevstvo ima posebno važnu ulogu u ovom političkom procesu, koji mu omogućava sigurniji i kraći put do nordijskog trougla (Island, Norveška i Grenland), a potom i ostvarivanja polarnih ambicija. ${ }^{40}$ Zajednički interes Grenlanda i Ujedinjenog Kraljevstva, između ostalog, počiva na identičnom stavu prema politici EU. Uprkos činjenici da je 70\% stanovništva glasalo protiv pridruživanja, Grenland je 1973. godine primljen u Evropsku zajednicu. Nakon 1979. godine i sve većih tenzija oko prava na ribolov, usledilo je održavanje referenduma koji ishodi povlačenjem Grenlanda iz Evropske zajednice 1985. godine..$^{41}$ Tada je doneta odluka o delimičnom napuštanju EU, zbog zabrinutosti da bi politika Brisela mogla da zahteva neograničeni pristup njegovim vodama za plovila svih država članica, čime se narušavaju interesi Grenlanda kao ribolovnog ostrva. ${ }^{42}$

Podržavanje teritorijalnog otcepljenja Grenlanda predstavlja važan aspekt polarne strategije Ujedinjenog Kraljevstva. U svetlu identičnih strateških ambicija EU na Arktiku, produbljena saradnja Ujedinjenog Kraljevstva i Grenlanda može

39 "UK and Greenland strengthen cooperation on fisheries", 09/11/2020, Internet: https://www.gov.uk/government/news/uk-and-greenland-strengthen-cooperation-onfisheries, 10/06/2021.

${ }^{40}$ Lana Ollier, "Greenland: The UKS strategic partner in the North", Polar Connection, 19/08/2016, Internet: https://polarconnection.org/greenland-uk-strategic-partners/, $15 / 06 / 2021$.

${ }^{41}$ Klaus Karsten Pedersen, "Denmark and the European Security and Defence Policy", in: Alyson J.K. Bailes, Gunilla Herolf and Bengt Sundelius (eds.), The Nordic Countries and the European Security and Defence Policy, Oxford University Press, London, 2005, p. 47.

42 Kevin McGwin, "Greenland and the UK land a fisheries agreement", Arctic Today, 10/ 11/2020, Internet: https://www.arctictoday.com/greenland-and-the-uk-land-a-fisheriesagreement/, 20/06/2021. 
biti tumačena kao još jedna negativna posledica Bregzita, koja podriva teritorijalni integritet Danske. Međutim, u političkoj igri sa Grenlandom, UK previđa jako važnu činjenicu da Kraljevina Danska još uvek ima odgovornost za odbranu svojih autonomnih oblasti, među kojima se pored teritorije Grenlanda, nalaze i Farska ostrva. Zadržavanje jedne ili dve velike fregate i tri obalne patrole u svakom trenutku u grenlandskim vodama, na 2.000 nautičkih milja od matičnih baza, veliki je zadatak danske mornarice. Međutim, veličina i lokacija Grenlanda prevazilaze njene trenutne odbrambene mogućnosti, što implicira da bi u slučaju neprijateljskog napada morala da se osloni na pomoć svojih saveznika. Identičan scenario se dogodio u toku Drugog svetskog rata, kada su SAD zaštitile Grenland od nemačke ofanzive i time zauzele strateški važnu tačku na putu ka Evropi. ${ }^{43}$ Prema navodima jednog od izveštaja EU za 2020. godinu, evoluiranje arktičke politike Ujedinjenog Kraljevstva poslednjih godina se anticipira kao pretnja i odraz rastućeg geopolitičkog interesa „ne-evropskih" zemalja da postanu deo savremenih bezbednosnih trendova nadomak severne ledene kape. ${ }^{44}$ Pesimističan scenario negativne integracije Danske navedenim tvrdnjama zadobija potpuno novu dimenziju, koja se ogleda u tome da EU i nordijska država gaje identičan stav prema strateškom delovanju UK na Arktiku. Obe strane percipiraju britansku polarnu strategiju kao pretnju, što daje potpuno novi smisao Grenlandu, kao jedinstvenoj prilici za sticanje novih saveznika i pomirenje različitih interesa u oblasti odbrambene politike.

\section{Zaključna razmatranje: sprečavanje Degzita}

Britanski model diferencirane integracije ukazuje na probleme koji mogu nastati u budućnosti, ukoliko dođe do produbljivanja integracija uz istovremeni porast evroskepticizma. ${ }^{45}$ Ideja vodilja ovog rada bila je da se u kontekstu Bregzita

\footnotetext{
${ }^{43}$ Klaus Karsten Pedersen, "Denmark and the European Security and Defence Policy", op. cit., p. 47.

${ }^{44}$ Petra Dolata, "A balanced Arctic Policy for the EU", In-depth Analysis, European Parlament, July 2020, Internet: https://www.europarl.europa.eu/RegData/etudes/IDAN/2020/60 3498/EXPO_IDA(2020)603498_EN.pdf. O ulozi EU u rešavanju arktičkog pitanja pogledati rad: Dušan Proroković, „Arktičko pitanje i njegov uticaj na evropsku bezbednost“, Politika nacionalne bezbednosti, god. VI, broj 1, 2015, str. 187-208.

${ }^{45}$ Maja Kovačević, „,Diferencirana integracija u Prostoru slobode, bezbednosti i pravde Evropske unije: slučaj Danske“, Godišnjak Fakulteta političkih nauka, XIV, broj 24, 2020, p. 50.
} 
i rastućih evropskih odbrambenih integracija, ispita razvoj podjednako lošeg scenarija Danske u okviru EU, koji autorka u radu prepoznaje kao potencijalni Degzit. Ključni motiv za ovakvo promišljanje sastoji se u trijumfalnom broju danskog opt-out, odnosno voljnog neučestvovanja u pojedinim oblastima saradnje EU. Prema stanovištu koje zastupamo u radu, navedeni procesi generišu veliki pritisak evropskih državnika na povlačenje danskog opt-out u oblasti odbrambene politike. Neutemeljenost njihovog pristupa počiva na periodičnim diplomatskim naporima, koji ne vode pomirenju različitih interesa, već opravdanom širenju evroskeptičnog raspoloženja. Priliku za konstruktivno preispitvanje kopenhaške politike vidimo u pronalaženju zajedničkog rešenja za Grenland. Poslednjih godina Ujedinjeno Kraljevstvo pokušava da se posredstvom jakih bilateralnih veza sa danskim ostrvom, etablira kao jedan od vodećih polarnih igrača na Arktiku. Za Dansku ovo može biti problematično iz više razloga, među kojima se posebno ističu britanska podrška teritorijalnom otcepljenju Grenlanda i njegova sposobnost samostalnog zaključivanje sporazuma u vezi maritimnih pitanja. Gledano iz perspektive EU, reč je o nekadašnjoj državi članici koja preferira evroatlantističku komponentu i raspolaže nuklearnim naoružanjem. Na temelju izvedenih tvrdnji, zajedničko rešenje u vezi Grenlanda podrazumevalo bi da Kraljevina Danska povlačenjem izuzeća u oblasti odbrambene politike EU dobija novog saveznika u odvraćanju potencijalnih vojnih agresora. Druga strana medalje je da može uticati na zaključivanje sporazuma između EU i Grenlanda u svoju korist, kako bi obezbedila viši stepen kontrole nad pravnom sposobnošću ostrvske autonomne oblasti. lako povlačenje izuzeća predstavlja kardinalnu promenu statusa u odbrambenoj politici EU, Danska time prevazilazi negativne oblike integracione dileme. Naznačeni kompromis može imati podjednako iste, ako ne i veće benefite za EU, koja povlačenjem danskog opt-out eleminiše poslednju kopiju britanskog modela. Za EU približavanje Grenlandu predstavlja važan korak u ostvarivanju njenih strateških ambicija, budući da još uvek nije direktno uključena u političke procese donošenja ključnih odluka o budućnosti Arktika. Naposletku možemo zaključiti da je reč o alternativnom pristupu, koji rešavanjem problema unutrašnje kohezije pozitivno utiče na više strateških pravaca razvoja EU. Navedena analiza pokazala je da se male države članice EU moraju prilagoditi trenutnom razvoju situacije, ukoliko ne žele da postanu taoci političkih odluka velikih sila. Na osnovu dosadašnjih zapažanja može se utvrditi da je ova nordijska zemlja propustila važnu lekciju o malim državama, koje bi trebalo da koriste položaj marginalnih igrača za uticaj na odabranu i relevantna pitanja. Primenu 
ovakve strategije „pametne države“ Danska može započeti jedino putem institucionalne fleksibilnosti i maksimiziranjem uticaja na donošenje odluka pod okriljem Evropskih institucija. ${ }^{46}$

\section{Bibliografija}

Adler-Nissen, Rebecca, "The Diplomacy of Opting-out: A Bourdieudian Approach to National Integration Strategies", Journal of Common Market Studies, Volume 46, No. 3, 2008, pp. 663-684.

Biscop, Sven, "European Defence: Give PESCO a chance", Survival, Vol. 60, No. 3, 2018, pp. 161-180.

Blockmans, Steven and Macchiarini Crosson, Dylan, "Differentiated integration within PESCO - clusters and convergence in EU defence", Research Report, Center for European Studies Policy, 04/2019.

Dominik, Schraff and Frank, Schimmelfennig, "Does differentiated integration strengthen the democratic legitimacy of the EU? Evidence from 2015 Danish opt-out referendum", European Union Politics, Vol. 21, No. 4, 2020, pp. 590-611.

Fiala, Vlastimil, "Decisions Concerning the 'Opt-Out' as an Instrument for Protecting National Interests", Contemporary European Studies, No. 1, 2006, pp. 53-70.

Garberg Bredesen, Maren, "The Shifting Boundaries of Nordic Defence Cooperation", Research paper, Norwegian Institute of International Affairs, 2020.

Hristov, Neno, "European Intervention Initiative vs Common European Army", International E-Journal of Advances in Social Sciences, Vol. IV, Issue 12, December 2018, pp. 691-696.

Huntley, David Matthew, "European defence policy at a crossroads - Germany preserving the status quo and France seeking change?", European Politics and Society, 2020, pp. 1-16.

\footnotetext{
${ }^{46}$ Anders Wivel, "The Security Challenge of Small EU Member States: Interests, Identity and the Development of the EU as a Security Actor", Journal of Common Market Studies, Volume 43, No. 2, 2005, p. 408.
} 
Kovačević, Maja, „Diferencirana integracija u Prostoru slobode, bezbednosti i pravde Evropske unije: slučaj Danske“" Godišnjak Fakulteta političkih nauka, XIV, broj 24, 2020, pp. 35-55.

Kovačević, Maja, Evropska diferencirana unija, Fakultet političkih nauka, Univerzitet u Beogradu, 2020.

Kuusik, Piret and Raik, Kristi, "The Nordic-Baltic Region in the EU: A Loose Club of Friends", European Policy Analysis, Swedish Institute for European Policy Studies, Issue 2018.

Larsen, Henrik, "Denmark and the ESDP opt-out: A new way of doing nothing?", in: Clive Archer (ed.), New Security Issues in Northern Europe: The Nordic and Baltic states and the ESDP, Routledge, London, 2008, pp. 78-94.

Leruth, Benjamin, Gänzle, Stefan and Trondal, Jarle, "Differentiated Integration and Disintegration in the EU after Brexit: Risks versus Opportunities", Journal of Common Market Studies, Volume 57, No. 6, 2019, pp. 1383-1394.

Miles, Lee, "Domestic influences on Nordic security and defence policy: from the perspective of fusion", in: Alyson J. K. Bailes, Gunilla Herolf and Bengt Sundelius (eds), Institutional and national politics, The Nordic Countries and the European Security and Defence Policy, International Peace Research Institute/Oxford University Press, Stockholm, 2006, pp. 77-98.

Mouritzen, Hans and Wivel, Anders, The Geopolitics of Euro-Atlantic Integration, Routledge, London, 2004.

Pedersen, Karsten Klaus, "Denmark and the European Security and Defence Policy", in: Alyson J.K. Bailes, Gunilla Herolf and Bengt Sundelius (eds), The Nordic Countries and the European Security and Defence Policy, Oxford University Press, London, 2005, pp. 37-50.

Petrović, Miloš, "Brexit kao ishod ambivalentne britanske politike prema evropskoj integraciji", Međunarodni problemi, Vol. LXXII, br. 3, 2020, str. 532-565.

Proroković, Dušan, "Arktičko pitanje i njegov uticaj na evropsku bezbednost", Politika nacionalne bezbednosti, god. VI, broj 1, 2015, str. 187-208.

Rieker, Pernille, "The Nordic countries and EU security policy: convergent or divergent agendas?", in: Alyson J. K. Bailes, Gunilla Herolf and Bengt Sundelius (eds.), Institutional and national politics, The Nordic Countries and the European Security and Defence Policy, International Peace Research Institute/Oxford University Press, Stockholm, 2006, pp. 301-314. 
Rye, Olsen Gorm and Pilegaard, Jess, "The Costs of Non-Europe? Denmark and the Common Security and Defence Policy", European Security, Volume 14, Issue 3, 2005, pp. 339-360.

Rynning, Sten, National Expectations regarding the European Defence Fund: The Danish Perspective, Armament Industry European Research Group, France, April 2020.

Schimmelfennig, Frank, Leuffen, Dirk and Rittberger, Berthold, "The European Union as a system of differentiated integration: interdependence, politicization and differentiation", Journal of European Public Policy, Vol. 22, No. 6, 2015, pp.764-782.

Sion, Maya, "The Politics of Opt-out in the European Union: Voluntary or Involuntary Defection?", Proceedings of the IWM Junior Fellows' Conference, Winter 2003.

Stahl, Bernard, Boekle, Henning, Nadoll, Jorg and Johannesdottir, Anna, "Understanding the Atlanticist-Europeanist Divide in the CFSP: Comparing Denmark, France, Germany and the Netherlands", European Foreign Affairs Review, Volume 9, Issue 3, 2004, pp. 417-441.

Stanković, Nevena, „Evropsko partnerstvo sa Norveškom", Evropsko zakonodavstvo, god. XIII, br. 51, 2015, str. 352-369.

Stanković, Nevena, „Glavne odrednice spoljne politike Emanuela Makrona“, Međunarodna politika, God. LXXI, br. 1179-80, 2020, str. 65-94.

Sweeney, Simon and Winn, Neil, "EU security and defence cooperation in times of dissent: analysing PESCO, the European Defence Fund and the European Intervention Initiative (EI2) in the shadow of Brexit", Defence Studies, Volume 20, Issue 3, 2020, pp. 224-249.

Wivel, Anders, "Between Paradise and Power: Denmarks Transatlantic Dillemma", Security Dialogue, Vol. 36, No. 3, September 2005, pp. 417-421.

Wivel, Anders, "The Security Challenge of Small EU Member States: Interests, Identity and the Development of the EU as a Security Actor", Journal of Common Market Studies, Volume 43, No. 2, 2005, pp. 393-412. 


\title{
THE POSITION OF THE KINGDOM OF DENMARK IN THE DEFENCE POLICY OF THE EUROPEAN UNION AFTER BREXIT
}

\begin{abstract}
A considerable number of opt-outs or voluntary non-participation in various areas of European Union cooperation is characteristic of the membership of the United Kingdom and the current position of the Kingdom of Denmark. During the discussions on the wobbly strategic perspective of the European Union, Brexit's warning note reached the issue of a possible withdrawal of other member states. Based on Denmark's differentiated participation in the European Union's Common Security and Defence Policy, this paper analyzes the potential of European helmsmen in reviewing the Copenhagen policy. The inertia of the Kingdom of Denmark has become particularly worrying during Brexit, which is accompanied by a process of growing European defence integration in the form of the PESCO program and the European Initiative for Intervention. A stronger stance of the European Union towards Denmark's exclusivity in the field of defence policy can also be expected based on the deepened bilateral ties between the United Kingdom and Greenland. The EU-Denmark-United Kingdom triangle of political relations is based on a strategic interest in Greenland, shifting the focus of their diplomatic and defence efforts from a strictly European area to the Arctic. The aim of this paper is to reveal the implications that Brexit may have on the special status of Denmark in the defence policy of the European Union as one of the new chapters on the path of its strategic autonomy and development.
\end{abstract}

Key words: Brexit, Kingdom of Denmark, United Kingdom, opt-out, European Union, Common Security and Defence Policy. 